\title{
Thermostability of chlorophylls in some native species of xerophytes
}

\author{
K.A. Farghali ${ }^{1,2}$ and Abeer A. El-Aidarous ${ }^{1}$ \\ ${ }^{1}$ Biology Department, Faculty of Applied Science, Umm Al-Qura University, K.S.A. \\ ${ }^{2}$ Botany Department, Faculty of Science, Assiut University, Egypt
}

\begin{abstract}
This study was carried out on eight wild species inhabited the tributaries of wadi Al Noman, at Holey Mecca in the western Kingdom of Saudi Arabia. The plant samples were collected at different locations, where laboratory analyses were included: the water content, chlorophyll content and its stability (CSI), , Mg ions, water soluble sugars and soluble proteins. The results showed that, the chlorophyll a content was higher than the chlorophyll $b$ in the studied species. The maximum value of chlorophylls existed in $C$. colocyanthis and $R$. viscarius, whereas $C$. russeliana had low content of chlorophyll a and chlorophyll $b$. The chlorophyll a/b ratio was balanced by the chlorophyll stability to heat. The CSI of chlorophyll a was compensated by CSI of chlorophyll $b$ and vice versa. The maximum values of total chlorophyll stability $(a+b)$ was found in annuals $C$. colocynthis and D. innoxia, whereas C. russeliana had low CSI. The different chlorophyll parameters were mainly affected by the interaction between wadi and species, and the species factor played the subsidiary role on the chlorophyll content and chlorophyll a/b ratio in most floristic groups, except in case of chlorophyll a of dominant species the wadi factor was subsidiary. There was no significant effect of single factor on CSI of different groups. The correlation of Mg ions, soluble sugars and soluble proteins with total chlorophyll content and CSI were discussed.
\end{abstract}

Key Words: Chlorophyll, thermostability, wild species, water content, $\mathrm{Mg}$ ions, soluble proteins, soluble sugars.

\section{Introduction}

Many wild or cultivated species inhabiting hot desert wadis under climate and edaphic variations should be subjected to changes in their photosynthetic potentials and biochemical activities. The amount of solar radiation absorbed by a leaf is largely a function of the foliar concentrations of photosynthetic pigments, and therefore low concentrations of chlorophyll can directly limit photosynthetic potential and hence primary production (Curran et al., 1990; Filella et al., 1995. Hence, the relative concentrations of pigments are known to change with abiotic factors such as light and so quantifying these proportions can provide important information about relationships between plants and their environment (Richardson et al., 2002).

A significant correlation between both Chl. content and CSI with water content, soluble proteins and $\mathrm{Mg}^{2+}$, was found, with the sign of the correlation dependent on the importance of the constituents to Chl. content and CSI in the studied species (Farghali,1998; Akinci et al.,2010). Therefore, the change in Chl. a/b ratio accompanied by low Chlorophyll contents in several halo-xerophytes can be can compensated by an increase in Chl. stability against the prevailing stress conditions.

This investigation aimed at determines and evaluate the photosynthetic pigments (chlorophyll $a$ chlorophyll $b$ content and stability o heat) and its relationships with Mg ionand main water soluble metabolites of investigated species. Statistical treatments of the data are carried to elucidate the effect of single factors (wadi and species) and their interaction on different parameters measured of plants.

\section{Materials and Methods}

This investigation was carried out on wild plants inhabiting 4 tributaries of wadi Al Noman at Holey Mecca in the western region of Kingdom of Saudi Arabia. Wadi Al Noman is located in the Western part of Saudi Arabia, between El Hada mountains in the East to the Red Sea coast in the West and extended between $21^{\circ} 06^{`}$ to $21^{\circ} 32^{`} \mathrm{~N}$ and $39^{\circ} 32^{`}$ to $40^{\circ} 20^{\circ} \mathrm{E}$. The soil and plant samples were collected from a number of sites (stands) which represent its distribution at different edaphic habitats in the investigated wadis. This work was carried during the period extending from January to April under the mild climatic condition.

\section{Plant analyses:}

Samples of 8 species inhabiting 4 tributaries of wadi Al Noman were chosen and collected from its habitats as the following: 5 species from wadi Kharar, 6species from wadi El-Shara, 8 species from wadi Magaresh and 8 species from wadi El-Kor. The investigated species were identified according to Täckholm, 
1974; Migahid 1978; Collenette, 1985 and Boulos (1995, 1999, 2000, 2002, 2005). These species including 5 perennials and 3 annuals (which belong to 8 families) were categorized into two groups as follows:

1- Dominant species (No. 1-4) were occupied 100\% of studied sites namely: Cleome droserifolia, Abutilon pannosum, Tephrosia desertorum and Citrullus colocyanthis.

2- Co-dominant species (No. 5-8) were inhabited $75 \%$ of sites were included: Heliotropium arbainense, Rumex vesicarius, Datura innoxia and Caralluma russeliana.

The plant samples were immediately transferred to plastic containers from their natural environments to the laboratory. Samples of leaves were washed with cold distilled water and thoroughly dried on filter paper. For each species three samples were chosen at random.

Determination of water content (as\%):

Water content in plant leaves was determined as a percentage of fresh weight. For each species, three samples were chosen at random, then oven-dried at $70^{\circ} \mathrm{C}$ for $24 \mathrm{hrs}$ and reweighed to calculate their water content as following equation:

$$
\% \text { of water content }=\text { Fresh weight of plant }- \text { dry weight of plant }
$$

\section{Determination of chlorophylls:}

At the same time, chlorophyll $a$ and chlorophyll $b$ were extracted using $85 \%$ acetone and determined according to Lichtenthaler (1987). To determine the chlorophyll stability index (CSI) a sample of fresh healthy leaf was placed in $20 \mathrm{ml}$ distilled water and heated in a water-bath at $56 \pm 1{ }^{\circ} \mathrm{C}$ for $30 \mathrm{~min}$, and the CSI calculated according to Murty and Majumder (1962) as the ratio of Chlorophyll content in heated leaf $\left(56 \pm 1^{\circ} \mathrm{C}\right)$ to that in fresh leaf, expressed as a percentage.

\section{Analyses of plant extracts:}

A known weight of fresh leaf sample was rapidly blended with $10 \mathrm{~cm}^{3}$ of ice cold distilled water and the supernatant was kept in deep freeze until analysis.

\section{Determination of water soluble metabolites and $\mathrm{Mg}$ :}

1-Soluble sugars were determined according to Dubois et al., (1956)

2- Total soluble proteins were determined according to Lowry et al., (1951).

3- Magnesium was determined by using Atomic Absorption Spectrophotometer according to Stewart (1974).

\section{Statistical analyses}

The effects of single factors (wadi and species) and their interaction (wadi x species) on the contents of chlorophylls and water soluble metabolites in different species were evaluated statistically by the analysis of variance ( $\mathrm{F}$ test). The relative role of each single factor and their interaction in the total response were determined by using the coefficient of determination $\left(\eta^{2}\right)$ to indicate the degree of control of the factor on the parameter tested (Ostle, 1963 and Ploxinki, 1969) as applied by EL-Sharkawi and Springuel (1977). A simple linear correlation coefficient (r.) between ion content in soils with their analogues in plants, correlation of total chlorophyll and chl. stability with $\mathrm{Mg}^{+2}$ ions and total chl. with soluble. sugars, and soluble proteins was tested according to Ostle (1963).

\section{1- Water content (as \%) :}

\section{Results}

The water content as a percentage of the fresh weight was variable among various species at investigated wadis (Figure 1). Obviously, the mean \% of water content of plants inhabited W. El-Kor was the lowest $(74.70 \%$ ) among species inhabited the rest wadi (its water content ranged between 78.72 to $80.45 \%$ ). Among species, the mean \% of water content tended to a maximum ( $89.80 \%$ ) in both $R$. vesicarius (annual) and C. russeliana as a succulent plants. While mean, a minimum value $(66.00 \%)$ was observed in A. pannosum, particularly at W. El-Kor. This may be a reflection of soil water conservation at wadis inhabited by studied species. In general, the percentages of water content were recorded a minimum values $(55.77-68.06 \%)$ in $A$. pannosum at W. El -Kor, W. Magaresh and W. Kharar; whereas in T. desertorum the same was true at W. El Shara.

Conversely, a maximum value of water content $(91.40 \%)$ were observed in R.vesicarius at both W. El-Kor and W. Kharar, in C. russeliana at both W. Magaresh and W. El-Shara, as well as, in D. innoxia at W. El-Shara.

F values (Table 1) showed a highly significant effect of the species and the interaction (wadi x species) factors on the water content in species of different groups, whereas the wadi factor had no significant effect. 
Therefore, the interaction (wadi x species) had a dominant role $\left(\eta^{2}=0.539\right.$, and 0.537 of dominant, and codominant species, respectively) and the species factor had a subsidiary effect on the water contents in species .

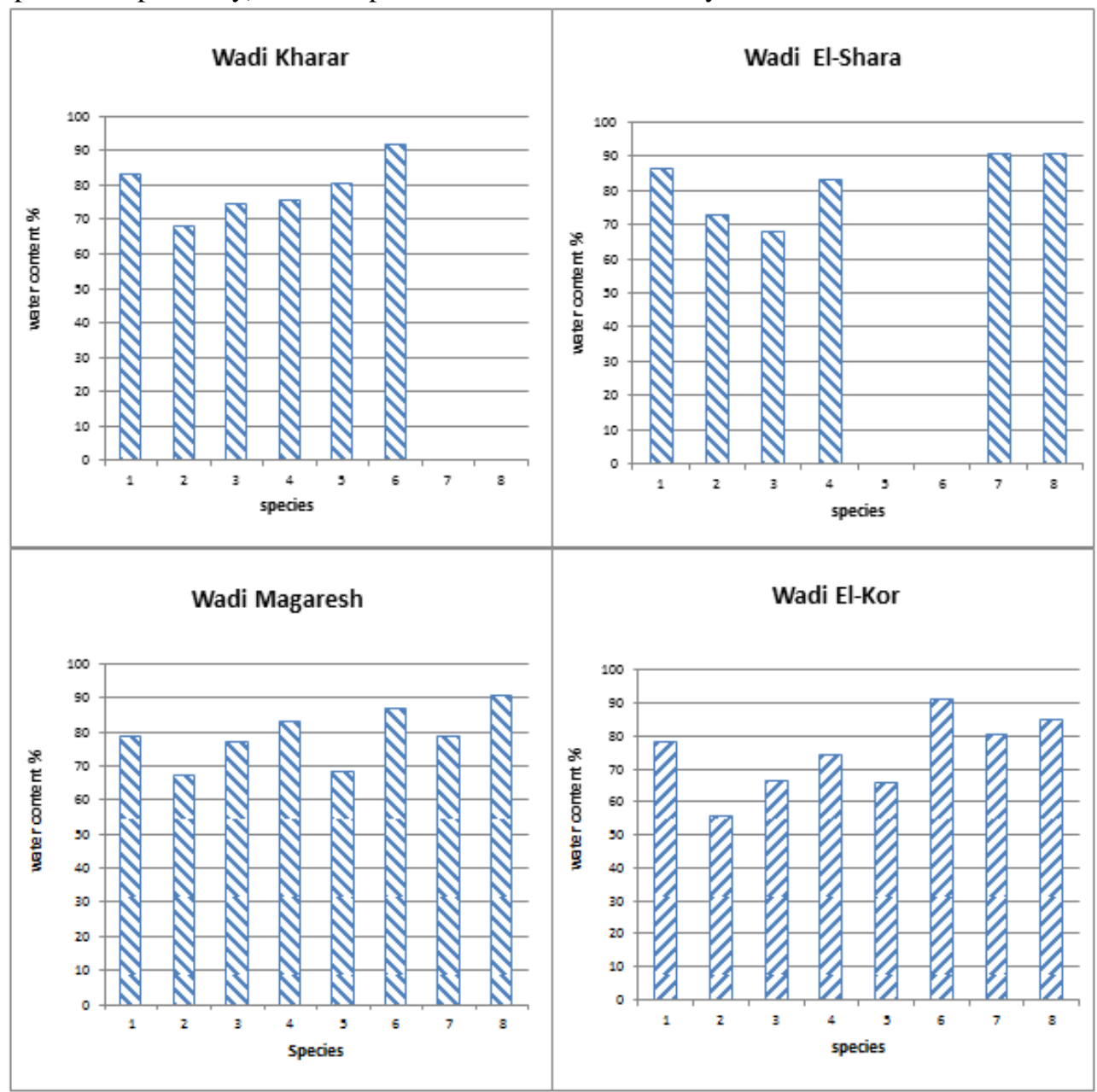

Figure (1): Average values of water content in different species inhabiting wadi Kharar, wadi El- Shara, wadi Magaresh and wadi El-Kor:(1) C. droserifolia; (2) A.pannosum; (3) T. desertorum; (4) C. colocynthis; (5) H. arbainense; (6) R.vesicarius; (7) D. innoxia; (8) C. russeliana.

\section{2- Chlorophyll content, $a / b$ ratio and stability index :}

a- Chlorophyll content (fractions \& total) :

plants (Figures 2-4). It is found that, chlorophyll $a$ and $b$ tended to a maximum (e.g. 2.74 and 2.28 mg.g g $^{-1}$ fresh weight in A. pannosum) in species inhabited W. El-Kor. At the same wadi, the minimum value (0.063 and $0.028 \mathrm{mg} . \mathrm{g}^{-1}$ fresh weight) was detected in the succulent species $C$. russeliana at different wadis studied. It seems that, the average chlorophyll $a$ content in dominant species was $2.36-1.89$ mg. $\mathrm{g}^{-1}$ fresh weight and in codominant species was 2.15-0.197 mg. $\mathrm{g}^{-1}$ fresh weight. While mean, chlorophyll $b$ content was ranged between 1.57 to $0.87 \mathrm{mg} . \mathrm{g}^{-1}$ fresh weight in dominant species, 1.23 to 0.09 fresh weight and in co-dominant species. The summation of chlorophyll $a$ and $b$ content (Figure 9) indicated that, A. pannosum had a high value (5.02 mg.g g $^{-1}$ fresh weight) at W. El-Kor, whereas $C$. rasseliana had a low chlorophyll contents not only in W. El-Kor, but also at W. Magaresh and W. El-Shara . In general, the average values of the total chlorophyll were high (4.52 to $2.76 \mathrm{mg} . \mathrm{g}^{-1}$ fresh weight) in dominant species compared to that values in co-dominant (3.38-0.29 $\mathrm{mg}^{-\mathrm{g}^{-1}}$ fresh weight). Obviously, the total chlorophyll or its fractions (Chl. $a$ or chl. $b$ ) of each species were differed among wadis investigated.

Statistically, the chlorophyll $a$, chlorophyll $b$ and total chlorophyll contents were significantly affected by wadi, species and their interaction factors with few exceptions (Table,1). It was found that, (wadi x species) interaction had a dominant role (Judged by $\eta^{2}$ ) on the chlorophyll content of species in different floristic groups. Meanwhile, the wadi factor had a secondary role on the chlorophyll $a$ and total chlorophyll of the dominant species, the species factor had a secondary effect on chlorophyll $b$. Likewise, the species factor had a subsidiary role on chlorophyll $a$, chlorophyll $b$ and total chlorophyll of co-dominant species. 


\section{b- Chlorophyll $a / b$ ratio :}

It was noticed that, the chlorophyll $a / b$ ratio had a values ranging between 3.23 and 1.48 , where the majority of the ratios in tested species above 2.0 (Figure 5). Meanwhile, the mean value of species at wadi ElKor was the lowest (1.92), the highest mean value (2.33) was showed in species at W. El-Shara. In general, the mean ratios among species, regardless of its wadis were differed and ranged between 2.74 in $H$. arbainense to 1.62 in $T$. desetorum. It seems that, the highest chlorophyll content $a \& b$ corresponding to the lowest chlorophyll $a / b$ ratio and vice versa. This may be due to chlorophyll balanced in wild species as adaptive features in plants responded to high light intensities prevailing in the wadis under investigation. $F$ values (Table 1) indicated that, the wadi, species and their interaction factors had a highly significant effect on the chlorophyll $a / b$ ratio, except wadi factor in co-dominant species. The determination coefficient $\left(\mathrm{n}^{2}\right)$ indicated that, the interaction (wadi x species) had a dominant role on the chlorophyll ratio of dominant and co-dominant species ( 0.575 and 0.629 respectively) and the role of species factor was subsidiary.

\section{c-Chlorophyll stability index (CSI) :}

The thermostability of both chlorophyll $a$ and chlorophyll $b$ of plants studied were shown in Figure (68 ). At wadi Kharar and wadi Magaresh, $H$. arbainense and D. innoxia (also T. desertorum) held the highest CSI percentage of chlorophyll $a$ (91.09 and $91.96 \%$, respectively). The same was true for CSI of chlorophyll $b$ in case of $H$. arbainense. The lowest CSI of chlorophyll $b(41.1 \%)$ was noticed in $C$. russeliana at W. El-Shara.
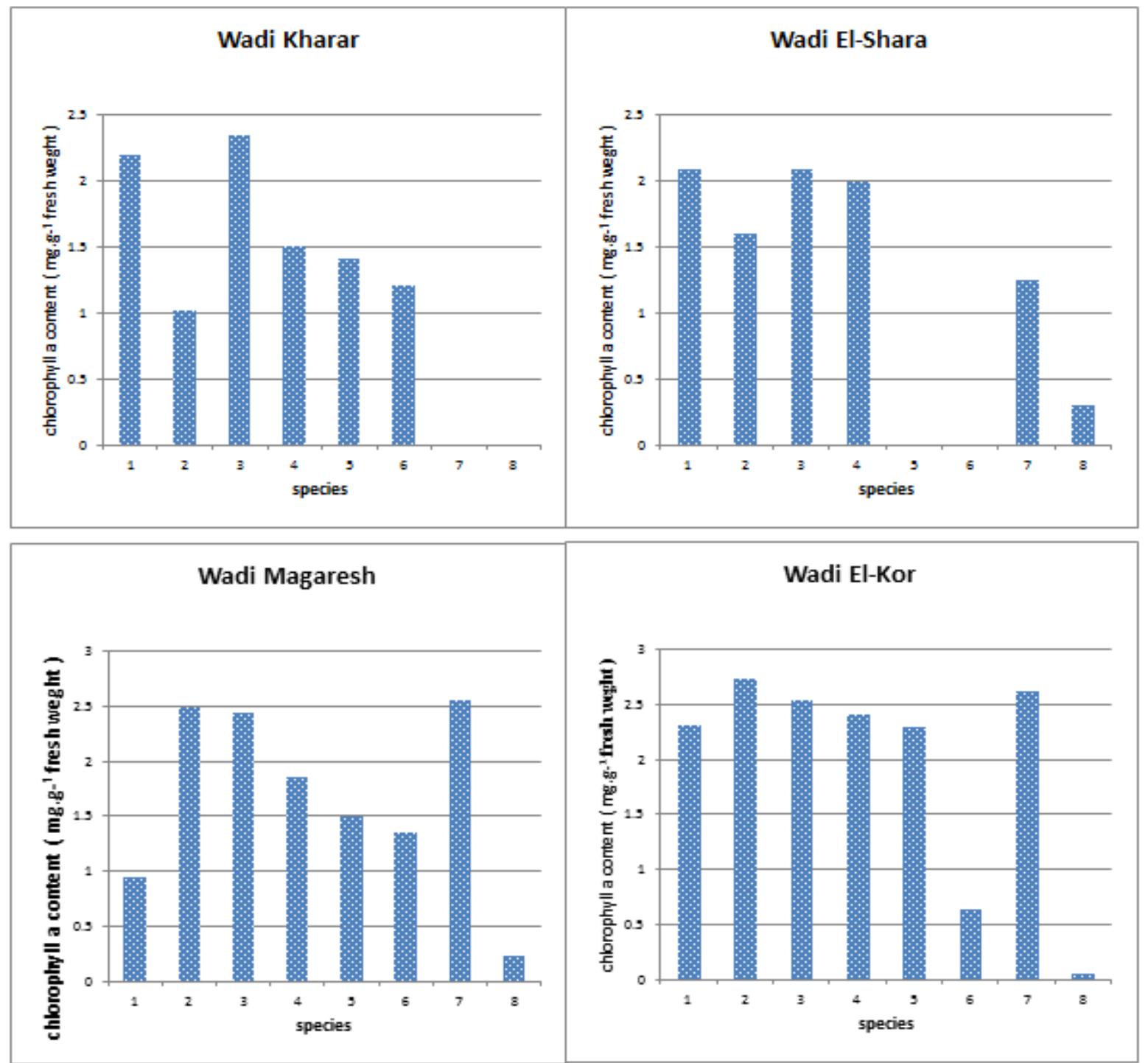

Figure (2): Average values of chlorophyll (a) in different species inhabiting wadi Kharar,wadi El-Shara, wadi Magaresh and wadi El-Kor: (1) C. droserifolia; (2) A.pannosum; (3) T. desertorum; (4) C. colocynthis; (5) H. arbainense; (6) R.vesicarius; (7) D. innoxia; (8) C. russeliana. 


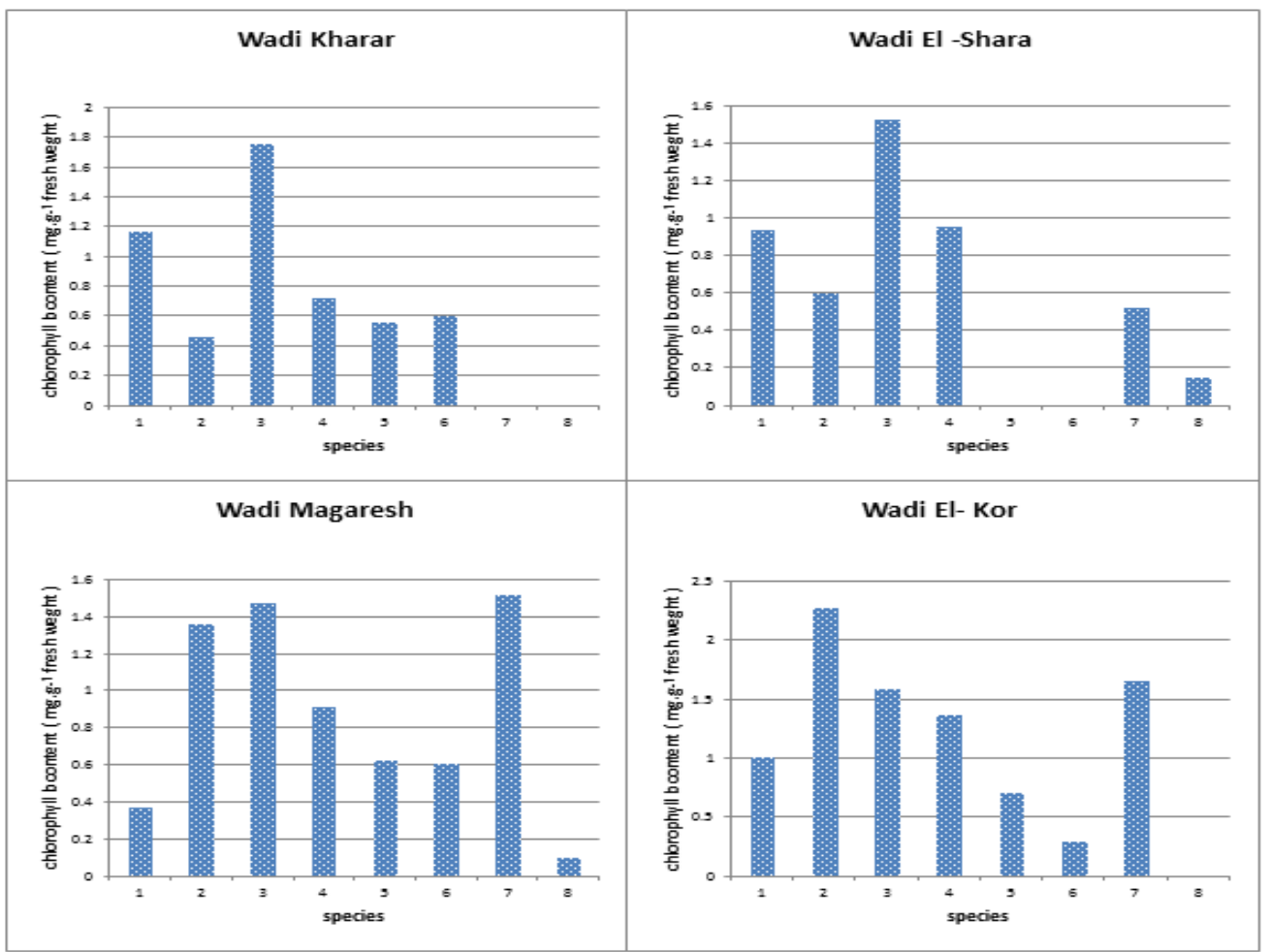

Figure (3): Average values of chlorophyll $(b)$ in different species inhabiting wadi Kharar, wadi El-Shara, wadi Magaresh and wadi El-Kor (1) Cleome droserifolia; (2) Abutilon pannosum; (3) Tephrosia desertorum; (4) Citrullus colocynthis; (5) Heliotropium arbainense; (6) Rumex vesicarius; (7) Datura innoxia; (8) Caralluma russeliana.

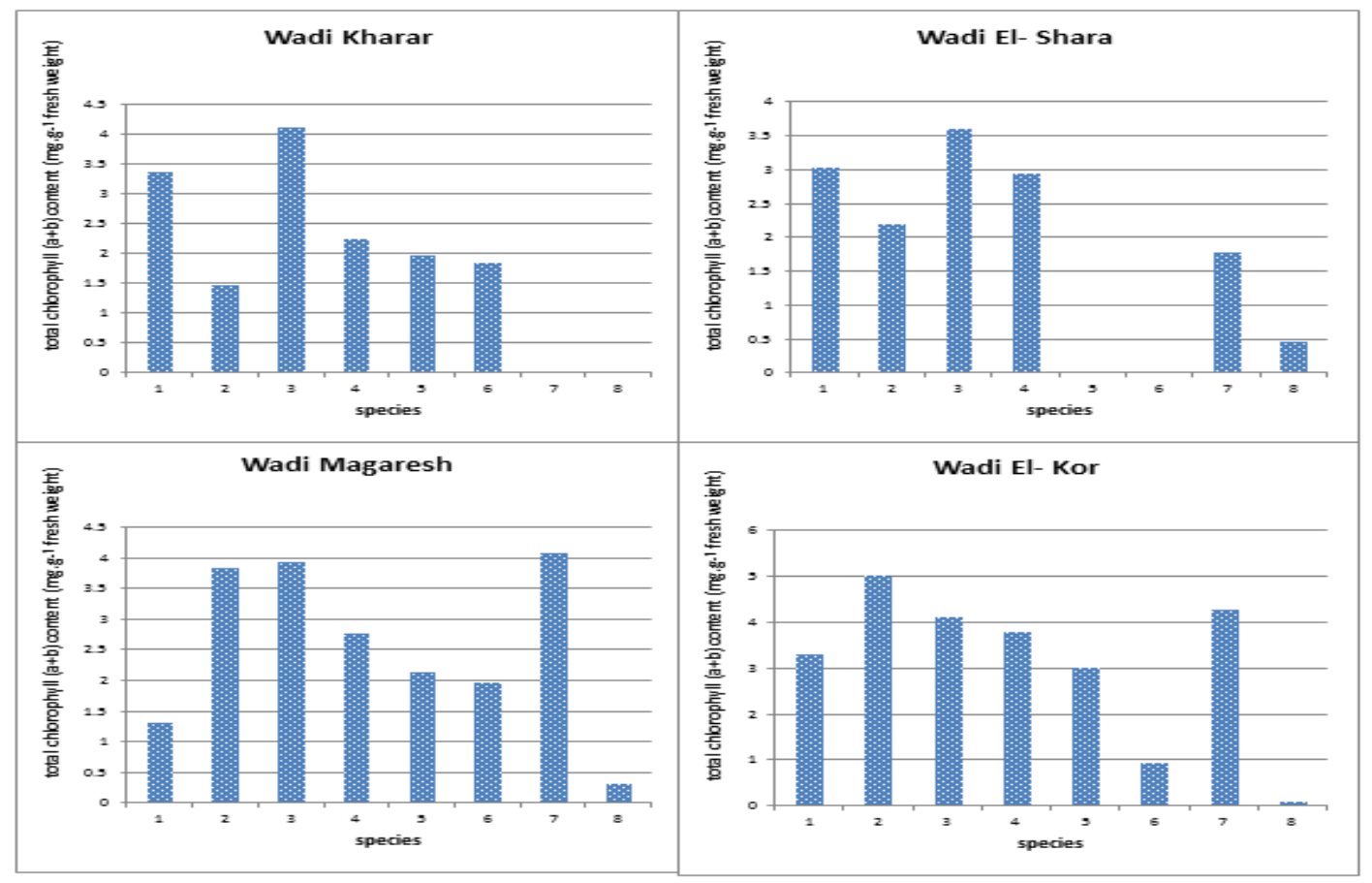

Figure (4): Average values of chlorophyll $(a+b)$ in different species inhabiting wadi Kharar, wadi El-Shara, wadi Magaresh and wadi El -Kor (1) Cleome droserifolia; (2) Abutilon pannosum; (3) Tephrosia desertorum;

(4) Citrullus colocynthis; (5) Heliotropium arbainense; (6) Rumex vesicarius; (7) Datura innoxia; (8) Caralluma russeliana.

Statistically (Table 1), the interaction between wadi \& species had a highly significant effect on the CSI of chlorophyll $a$, chlorophyll $b$ and total CSI in both dominant and co-dominant species, which had the 
predominant role $\left(\eta^{2}=0.815-0.660\right)$. Also, the species factor had a significant effect on the CSI of chlorophyll $a$ of co-dominant species, which was played a secondary role $\left(\eta^{2}=0.266\right)$.

Table (1): ANOVA test showed the effect of wadis, species and their interaction on the water content, chlorophyll content, stability and chlorophyll $a / b$ ratio of investigated species .

\begin{tabular}{|c|c|c|c|c|c|}
\hline \multirow{2}{*}{ contents } & \multirow{2}{*}{$\begin{array}{l}\text { Group of species } \\
\text { Source of variance }\end{array}$} & \multicolumn{2}{|c|}{ Dominate sp. } & \multicolumn{2}{|c|}{ Co dominate sp. } \\
\hline & & $\mathbf{F}$ & $\eta 2$ & $\mathbf{F}$ & $\eta 2$ \\
\hline \multirow{3}{*}{$\begin{array}{l}\text { Water } \\
\text { content }\end{array}$} & Wadi & 2.748 & 0.090 & 2.572 & 0.106 \\
\hline & species & $27.076^{* *}$ & 0.371 & $20.606 * *$ & 0.358 \\
\hline & Wadi $x$ species & $34.848^{* *}$ & 0.539 & $191.025 * *$ & 0.537 \\
\hline \multirow{3}{*}{ Chl. $a$} & Wadi & $4.628 *$ & 0.203 & 0.815 & 0.0413 \\
\hline & species & 1.791 & 0.092 & $26.749 * *$ & 0.416 \\
\hline & Wadi $\mathrm{x}$ species & $10.502^{* *}$ & 0.705 & $29.843^{* *}$ & 0.543 \\
\hline \multirow{3}{*}{ Chl. $b$} & Wadi & $6.468 * *$ & 0.200 & 0.813 & 0.042 \\
\hline & species & $7.524 * *$ & 0.222 & $21.303 * *$ & 0.395 \\
\hline & Wadi $x$ species & $16.301 * *$ & 0.578 & $40.402 * *$ & 0.563 \\
\hline \multirow{3}{*}{ Chl. $a+b$} & Wadi & $6.916^{* *}$ & 0.220 & 0.846 & 0.042 \\
\hline & species & $5.472 * *$ & 0.187 & $26.045^{* *}$ & 0.410 \\
\hline & Wadi $\mathrm{x}$ species & $13.483^{* *}$ & 0.593 & $40.968 * *$ & 0.548 \\
\hline \multirow{3}{*}{ Chl. $a / b$} & Wadi & $4.328^{*}$ & 0.156 & 0.268 & 0.023 \\
\hline & species & $9.559 * *$ & 0.270 & $6.320 * *$ & 0.348 \\
\hline & Wadi $x$ species & $11.321 * *$ & 0.575 & $4.500 * *$ & 0.629 \\
\hline \multirow{3}{*}{ CSI $a$} & Wadi & 0.907 & 0.082 & 1.032 & 0.074 \\
\hline & species & 1.151 & 0.103 & $4.987 *$ & 0.266 \\
\hline & Wadi $\mathrm{x}$ species & $2.928^{*}$ & 0.815 & $8.222 * *$ & 0.660 \\
\hline \multirow{3}{*}{ CSI $b$} & Wadi & 1.550 & 0.101 & 0.432 & 0.038 \\
\hline & species & 2.116 & 0.133 & 2.773 & 0.199 \\
\hline & Wadi x species & $5.604 * *$ & 0.767 & $8.135 * *$ & 0.763 \\
\hline \multirow{3}{*}{ CSI $a+b$} & Wadi & 0.779 & 0.063 & 0.378 & 0.034 \\
\hline & species & 1.589 & 0.122 & 3.078 & 0.224 \\
\hline & Wadi $\mathrm{x}$ species & $3.969 * *$ & 0.814 & $6.255^{* *}$ & 0.742 \\
\hline & D.F & \multicolumn{2}{|c|}{$\begin{array}{c}\text { Wadi }=3 \quad s p=3 \\
\text { wadi } x \text { sp=15 }\end{array}$} & \multicolumn{2}{|c|}{$\begin{array}{c}\text { Wadi }=2 \quad s p=3 \\
\text { wadi } x \text { sp=11 }\end{array}$} \\
\hline
\end{tabular}

*Significant at $\mathrm{P}<0.05$ level, $\quad * *$ Significant at $\mathrm{P}<0.01$ level

Apparently, in most species the thermostability of chlorophyll $a$ was higher than that of chlorophyll $b$. Among wadis, the mean CSI of chlorophyll $a$ in different species was increased at W. Magaresh, while species produced a minimum CSI value at $\mathrm{W}$. El-Shara and vice versa for CSI of chlorophyll $b$. The total thermostability of chlorophyll (CSI $a+$ CSI $b$ ) in plants inhabited tributaries of wadi Al Noman was variable among wadis studied. Meanwhile, the highest mean value of CSI was

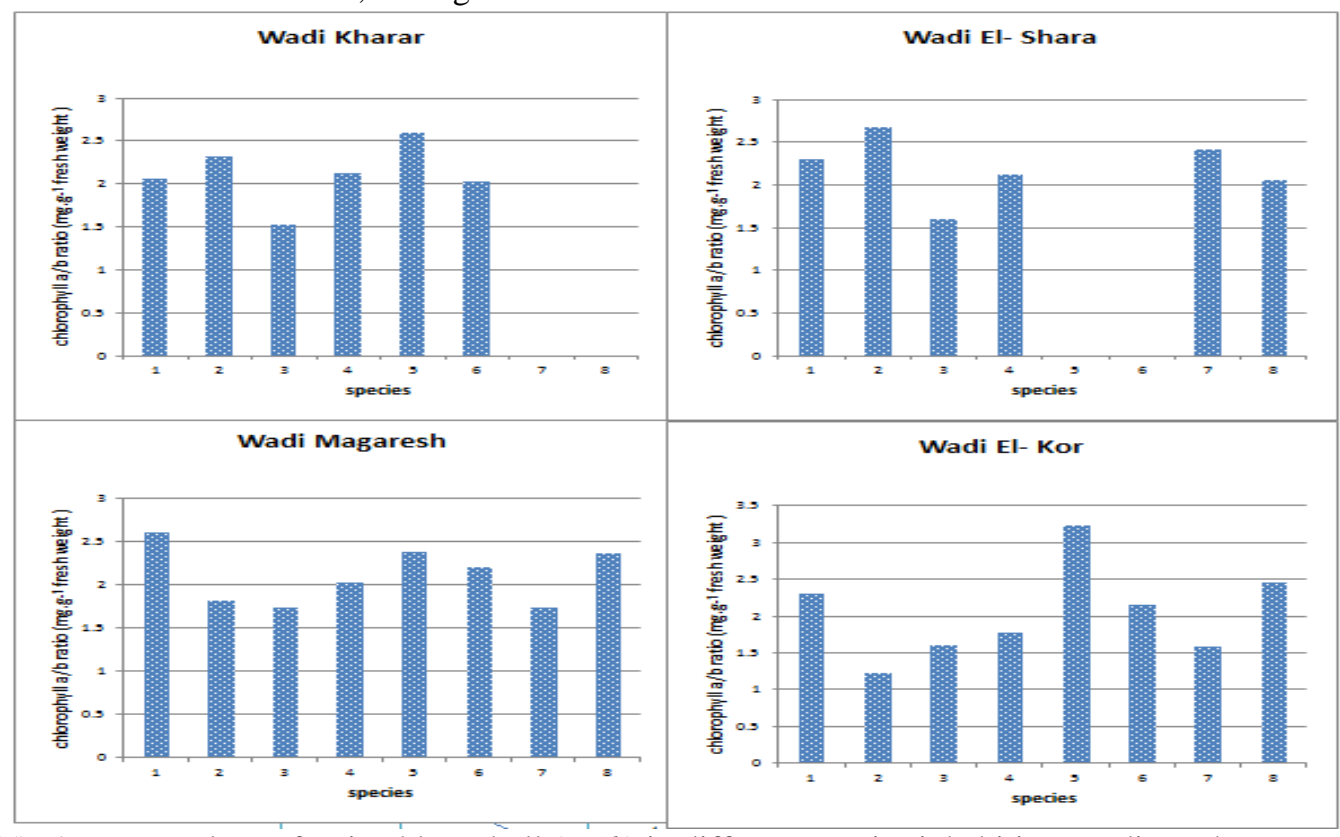

Figure (5): Average values of ratio chlorophyll $(a / b)$ in different species inhabiting wadi Kharar, wadi ElShara, wadi Magaresh and wadi El- Kor: (1) Cleome droserifolia;(2) Abutilon pannosum; (3) Tephrosia desertorum; (4) Citrullus colocynthis; (5) Heliotropium arbainense; (6) Rumex vesicarius; 
(7) Datura innoxia; (8) Caralluma russeliana.

represented by $70.0 \%$ in species inhabited W. El-Kor, the lowest

mean value was showed in species at W. Kharar (67.0\%). Regardless of wadis, species namely: T. desertorum, C. colocynthis (dominant species), D. innoxia (co-dominant sp.) had a highest mean value of chlorophyll stability to heat. Whereas, the lowest mean of CSI was exerted by succulent $C$. russeliana (co-dominant species). Obviously, a maximum CSI $(a+b)$ was represented by $92.71 \%$ in $H$. arbainense at W. Kharar and the minimum value (48.9\%) was in C. colocynthesis at W. Magaresh.

The correlations between total chlorophyll content and CSI were shown in table (2). A significant negative correlation was found between chlorophyll content and its stability to heat in $C$. russeliana (succulent). However, the chlorophyll content was positively correlated with CSI in the rest common species. The correlations between water content with the content or stability of chlorophyll in dominant species were nonsignificant. In co-dominant species, only the water content in $H$. arbainense was positively correlated with CSI, while in case of D.innoxia had a negative correlation with chlorophyll content.

Table (2): Correlation coefficient (r.) values between total chlorophyll and its stability with water content in different studied species.

\begin{tabular}{|c|c|c|c|c|c|}
\hline $\begin{array}{l}\text { Species } \\
\text { group }\end{array}$ & Contents & $\begin{array}{c}\text { Total ch \& } \\
\text { water } \\
\text { content }\end{array}$ & $\begin{array}{c}\text { Total CSI \& } \\
\text { water } \\
\text { content }\end{array}$ & $\begin{array}{l}\text { Total ch \& } \\
\text { Total CSI }\end{array}$ & D.F \\
\hline \multirow{4}{*}{ 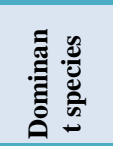 } & C. droserifolia & 0.381 & 0.265 & -0.707 & \multirow{4}{*}{$\prod_{i}^{\pi}$} \\
\hline & A.pannosum & -0.803 & -0.766 & 0.377 & \\
\hline & T.desertorum & -0.535 & 0.254 & -0.317 & \\
\hline & C. colocynthis & -0.235 & -0.576 & 0.145 & \\
\hline \multirow{4}{*}{ 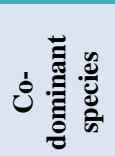 } & H. arbainense & -0.753 & $0.986^{*}$ & -0.632 & \multirow{4}{*}{ 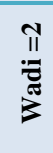 } \\
\hline & R. vesicarius & -0.534 & -0.102 & -0.787 & \\
\hline & D. innoxia & $-0.980 *$ & -0.070 & -0.137 & \\
\hline & C. russeliana & 0.878 & -0.870 & $-1.000 * *$ & \\
\hline
\end{tabular}

*Significant at $\mathrm{P}<0.05$ level **Significant at $\mathrm{P}<0.01$ level

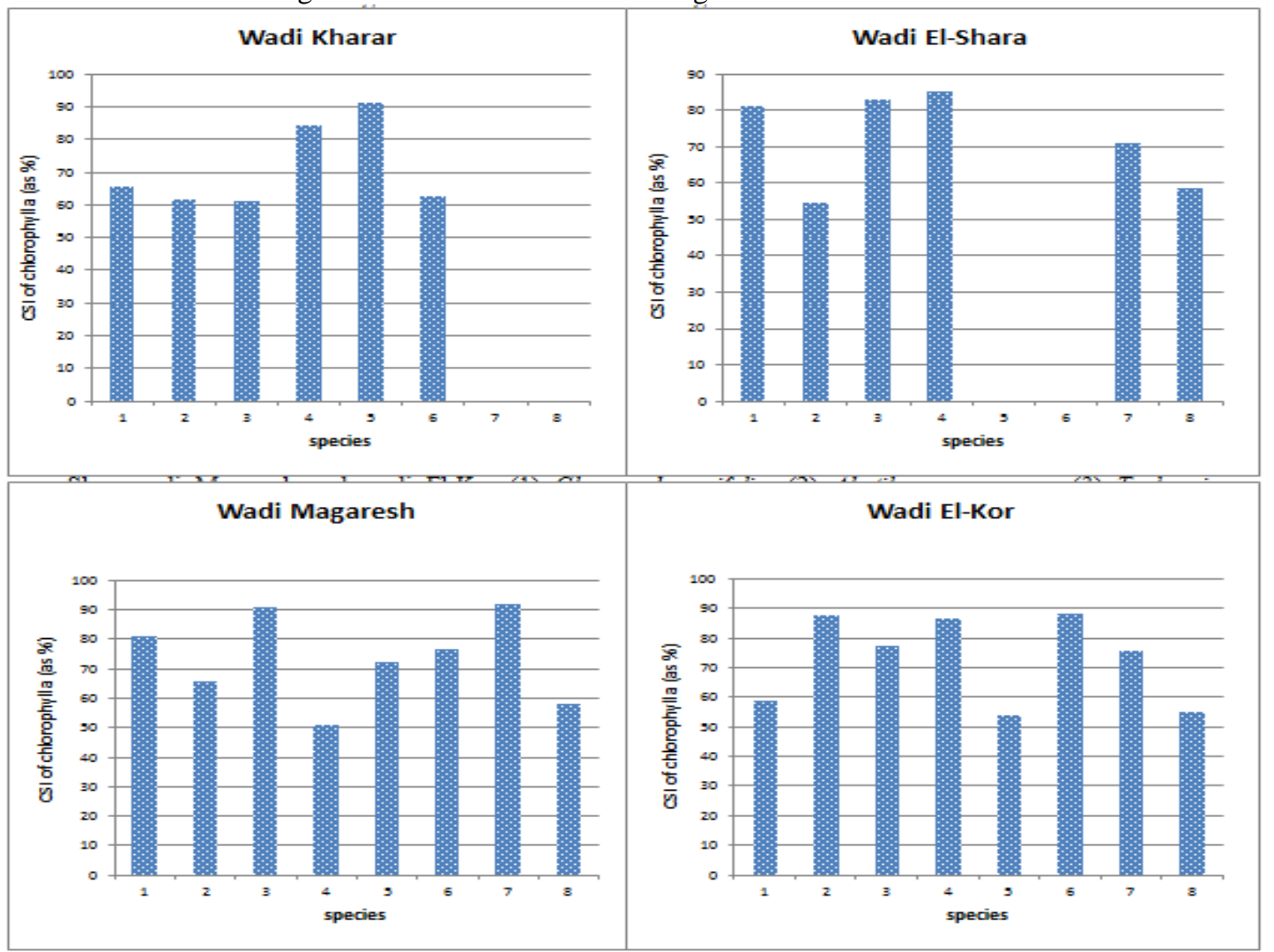

Figure (6): Average values of CSI chlorophyll $(a)$ in different species inhabiting wadi Kharar, wadi ElShara,wadi Magaresh and wadi El-Kor (1) Cleome droserifolia; (2) Abutilon pannosum; (3) Tephrosia desertorum; (4) Citrullus colocynthis; (5) Heliotropium arbainense; (6)Rumex vesicarius; (7) Datura innoxia; (8) Caralluma russeliana. 


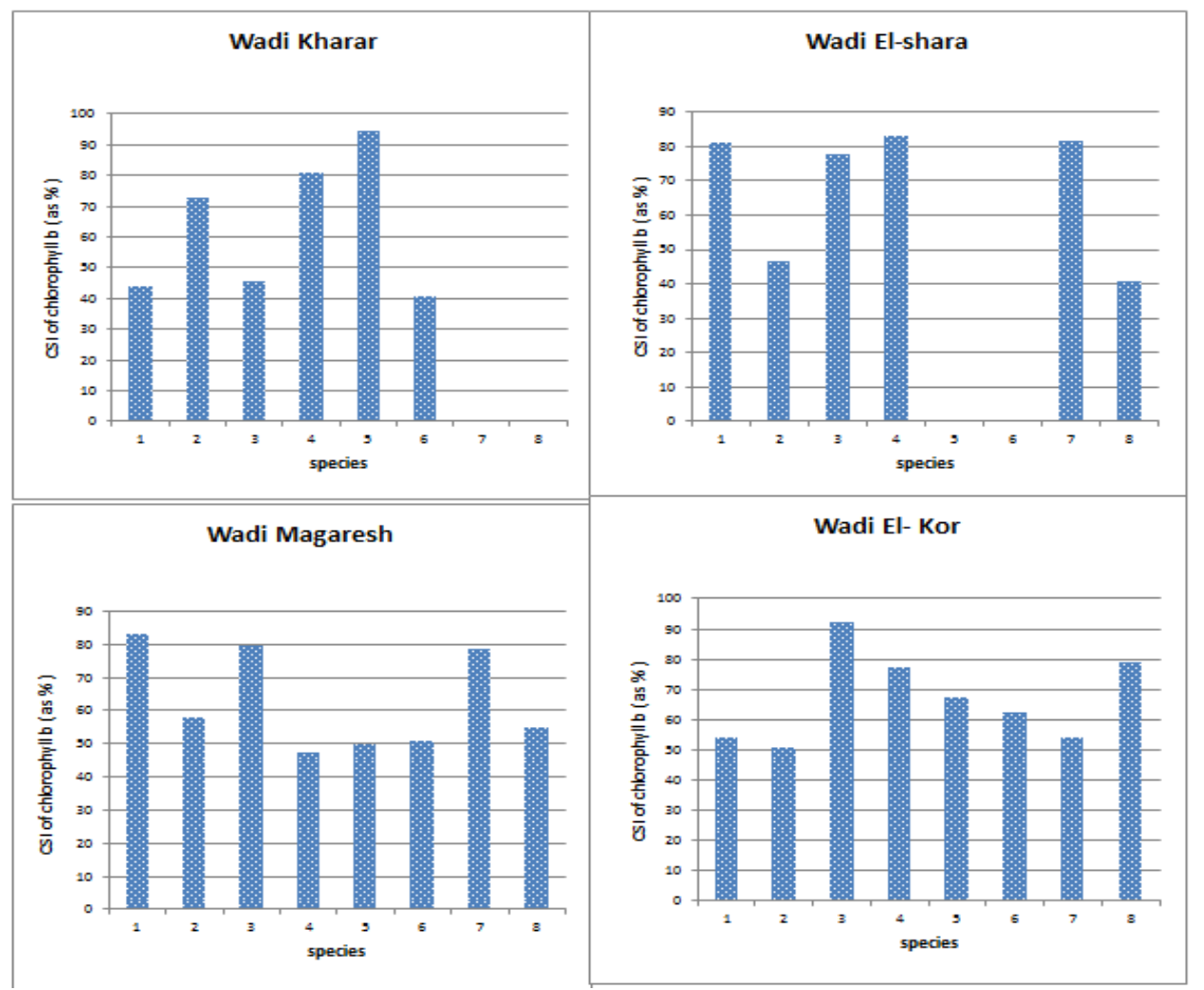

Figure (7): Average values of CSI chlorophyll $(b)$ in different species inhabiting wadi Kharar, wadi El-Shara, wadi Magaresh and wadi El-Kor (1) Cleome droserifolia; (2) Abutilon pannosum; (3) Tephrosia desertorum; (4) Citrullus colocynthis; (5) Heliotropium arbainense; (6) Rumex vesicarius; (7) Datura innoxia; (8) Caralluma russeliana.

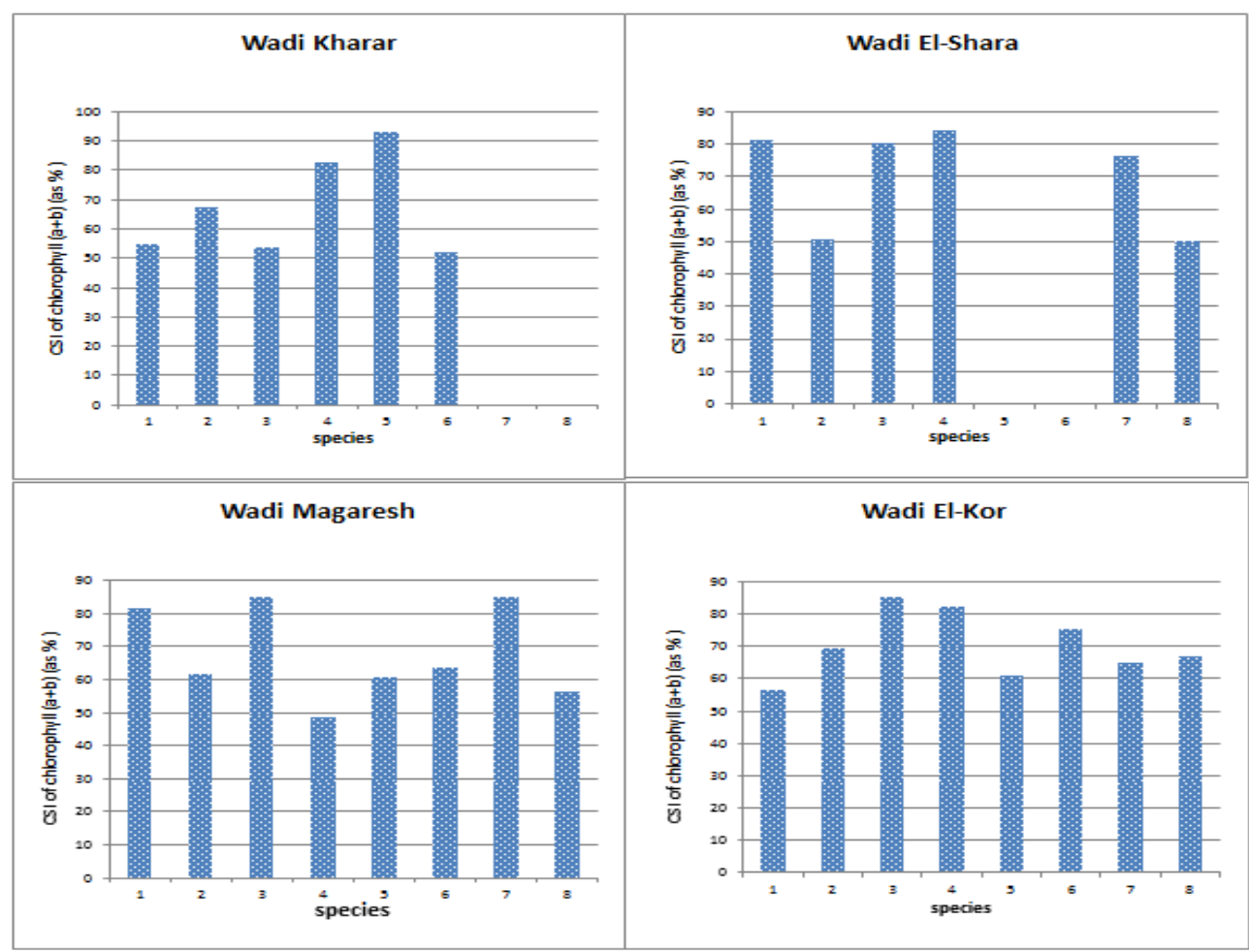

Figure (8): Average values of CSI of chlorophyll $(a+b)$ in different species inhabiting wadi Kharar, wadi ElShara, wadi Magaresh and wadi El-Kor: (1) C. droserifolia; (2) A.pannosum; (3) T. desertorum; (4) C. colocynthis;(5) H. arbainense; (6) R.vesicarius; (7) D. innoxia; (8) C. russeliana. 


\section{- Magnesium :}

Generally, the species inhabited W. El-Kor had a tendency to accumulated more $\mathrm{Mg}^{+2}$ than species inhabited the remaining wadis, particularly species inhabited W. El-Shara which had a lowest mean value of $\mathrm{Mg}^{+2}$ (0.183 mg. $\mathrm{g}^{-1}$ fresh weight). However, a maximum value ( $0.993 \mathrm{mg} \cdot \mathrm{g}^{-1}$ fresh weight) was recorded by $H$. arbainense at W. El-Kor, while a minimum value was existed in A. pannosum (0.041 mg.g ${ }^{-1}$ fresh weight) at W. Kharar. The same was true in case of C. droserifolia at W. El-Shara. (Figure 9).

$\mathrm{F}$ and $\eta^{2}$ values indicated that, the (wadi $\mathrm{x}$ species) interaction had a highly significant effect on $\mathrm{Mg}^{+2}$ content in species of all groups, which had a major role $\left(\eta^{2}=0.74\right.$ and 0.55 for dominant, and co-dominant species, respectively). However, wadi factor, had a significant effect and played a subsidiary role on $\mathrm{Mg}^{{ }^{2}}$ content of experimented species. However, the role of species factor was minor (Table 3).

Table (3): ANOVA test showed the effect of wadis, species and their interaction on $\quad \mathrm{Mg}$ of investigated species of different floristic groups.

\begin{tabular}{|c|c|c|c|c|c|}
\hline \multirow[b]{2}{*}{ contents } & \multirow{2}{*}{ Source of variance } & \multicolumn{2}{|c|}{ Dominant species } & \multicolumn{2}{|c|}{ Co dominant species. } \\
\hline & & $\mathbf{F}$ & $\eta 2$ & $\mathbf{F}$ & $\eta 2$ \\
\hline \multirow{3}{*}{ Mg } & Wadi & 3.592* & 0.173 & 5.358* & 0.335 \\
\hline & species & 1.619 & 0.087 & 1.391 & 0.116 \\
\hline & Wadi x species & $11.425^{* *}$ & 0.740 & $2.656^{*}$ & 0.550 \\
\hline
\end{tabular}

Significant at $\mathrm{P}<0.05$ level,

** Significant at $\mathrm{P}<0.01$ level

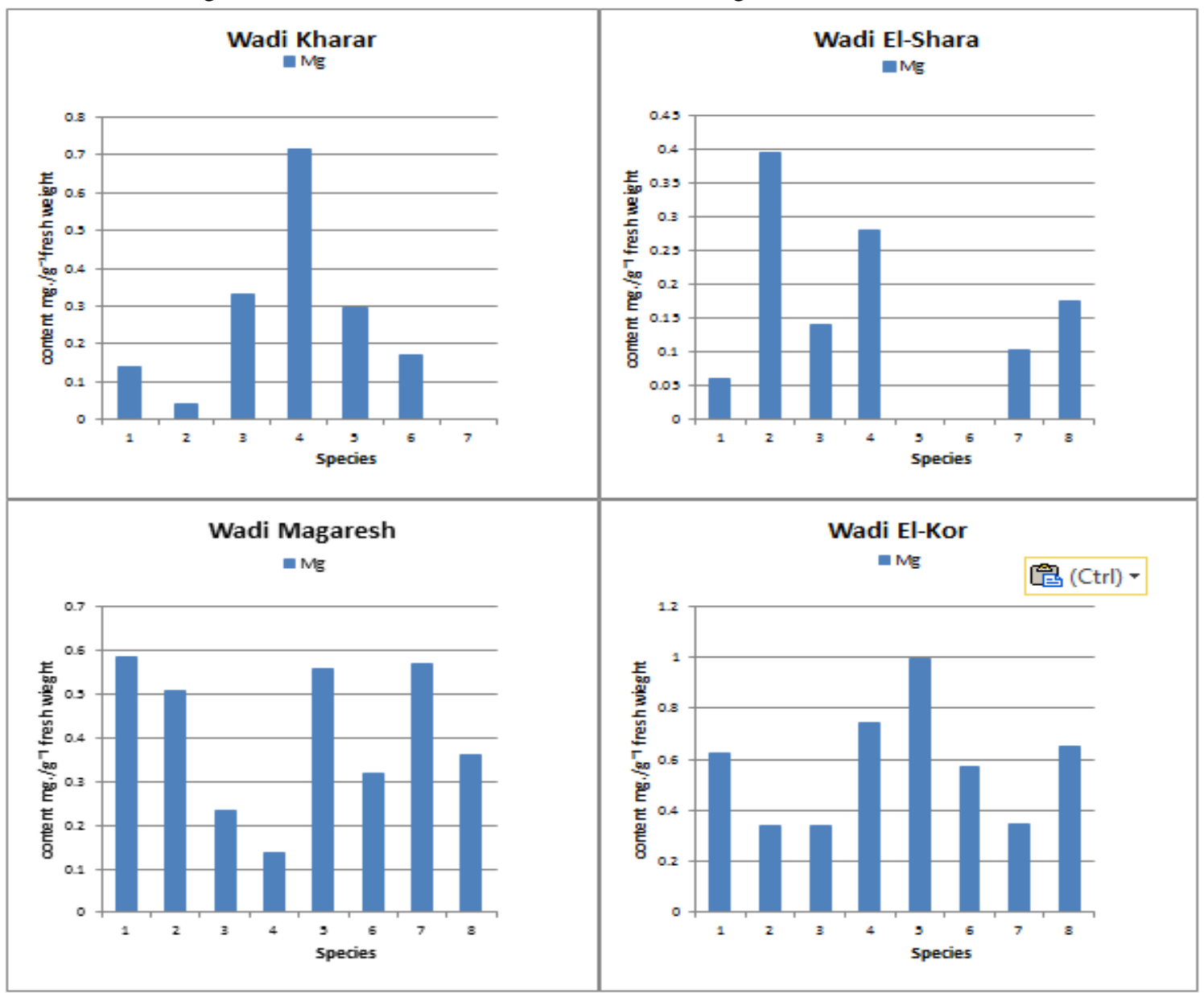

Figure (9): Average content of Mg in different species inhabiting wadi Kharar, wadi El-Shara, wadi Magaresh and wadi El-Kor: ( 1) C. droserifolia; (2) A.pannosum; (3) T. desertorum; (4) C. colocynthis;(5) H. arbainense; (6) R.vesicarius; (7) D. innoxia; (8) C. russeliana. 
Magnesium is an essential ion in the chlorophyll formation. Therefore, the correlation of $\mathrm{Mg}$ with both chlorophyll content and its stability to heat was variable among investigated species (Table 4). The significant positive correlation means that increased $\mathrm{Mg}$ ion was accompanied by an increasing in chlorophyll content and /or its stability to heat (e.g. H. arbainense, R.vesicarius and C. russeliana). Whereas, the negative correlation referred to a degradation of chlorophylls and /or decreased CSI of plants (e.g. C. russeliana) under natural wadis conditions.

Table (4): Correlation coefficient (r.) values between total chlorophyll and its stability with $\mathrm{Mg}$ ion in different studied species.

\begin{tabular}{|c|c|c|c|c|}
\hline $\begin{array}{l}\text { Floristicg } \\
\text { roup }\end{array}$ & species & Total ch \& Mg & Total CSI \& Mg & D.F \\
\hline \multirow{4}{*}{ 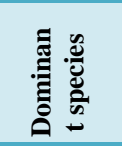 } & C.droserifolia & -0.460 & -0.066 & \multirow{4}{*}{$\prod_{\pi}^{\pi}$} \\
\hline & A.pannosum & 0.588 & -0.450 & \\
\hline & T.desertorum & 0.681 & -0.850 & \\
\hline & C. colocynthis & 0.190 & 0.685 & \\
\hline \multirow{4}{*}{ ن் } & H. arbainense & $0.974 *$ & -0.791 & \multirow{4}{*}{$\underset{\pi}{\pi}$} \\
\hline & R.vesicarius & -0.878 & $0.988^{*}$ & \\
\hline & D.innoxia & 0.845 & 0.415 & \\
\hline & C. russeliana & $-1.000 * *$ & $1.000 * *$ & \\
\hline
\end{tabular}

*Significant at $\mathrm{P}<0.05$ level $\quad * *$ Significant at $\mathrm{P}<0.01$ level

\section{3- Water soluble metabolites :}

a- Soluble sugars (S.S):

There was a differentiation in the soluble sugars content among experimented species at different wadis (Figure 10). A high content of soluble sugars (1.42 mg.g ${ }^{-1}$ fresh weight) was showed in T. desertorum, C. colocynthis at W. Kharar, C. russeliana, R. stricta at W. El-Shara and in D. innoxia at W. El-Kor. Whereas, a lowest value of S.S (0.073 mg.g ${ }^{-1}$ fresh weight) was existed in $R$. vescarius (annual), Regardless of species, a maximum mean value of S.S. (0.68 mg.g ${ }^{-1}$ fresh weight) was yielded by plants at W. Kharar, whereas species at W. El-Shara produced a minimum S.S content (0.38 mg.g ${ }^{-1}$ fresh weight). Among species, the high mean values of S.S. were showed in the dominant species and in D. innoxia and C. russeliana (co-dominant), whereas $H$. arbainense yielded a lowest S.S. content.

$F$ values indicate that, wadi as a single factor and its interaction with species factor had a significant effect on soluble sugars of dominant and co-dominant species (Table 5). The same was true in case of the species factor effect on S.S. in co-dominant species. Meanwhile, the role of thi and $s$ interaction was predominant on S.S. in species of different groups $\left(\eta^{2}=0.60\right.$ and 0.58$)$, the wadi factor had a secondary role on S.S. of dominant and co-dominant species $\left(\eta^{2}=0.35\right.$ and 0.24 , respectively).

\section{2-Total soluble proteins (S.P.):}

Obviously, the dominant species gained high contents of soluble proteins, especially in T. desertorum at various locations. Regardless of single species, all species inhabited W. Magaresh and W. El-Kor had a maximum mean value $\left(0.06 \mathrm{mg} . \mathrm{g}^{-1}\right.$ fresh weight $)$ of S.P., while a minimum mean value was in species inhabited wadi El-Shara (Figure 11).

F values (Table 5), showed that, wadi, species and their interaction had no significant effect on the soluble proteins of dominant species. Conversely, the wadi factor and its interaction with species had a significant effect on S.P. in co-dominant species. The interaction role was the dominant, while the role of wadi was subsidiary on S.P. contents in case of co-dominant species. 


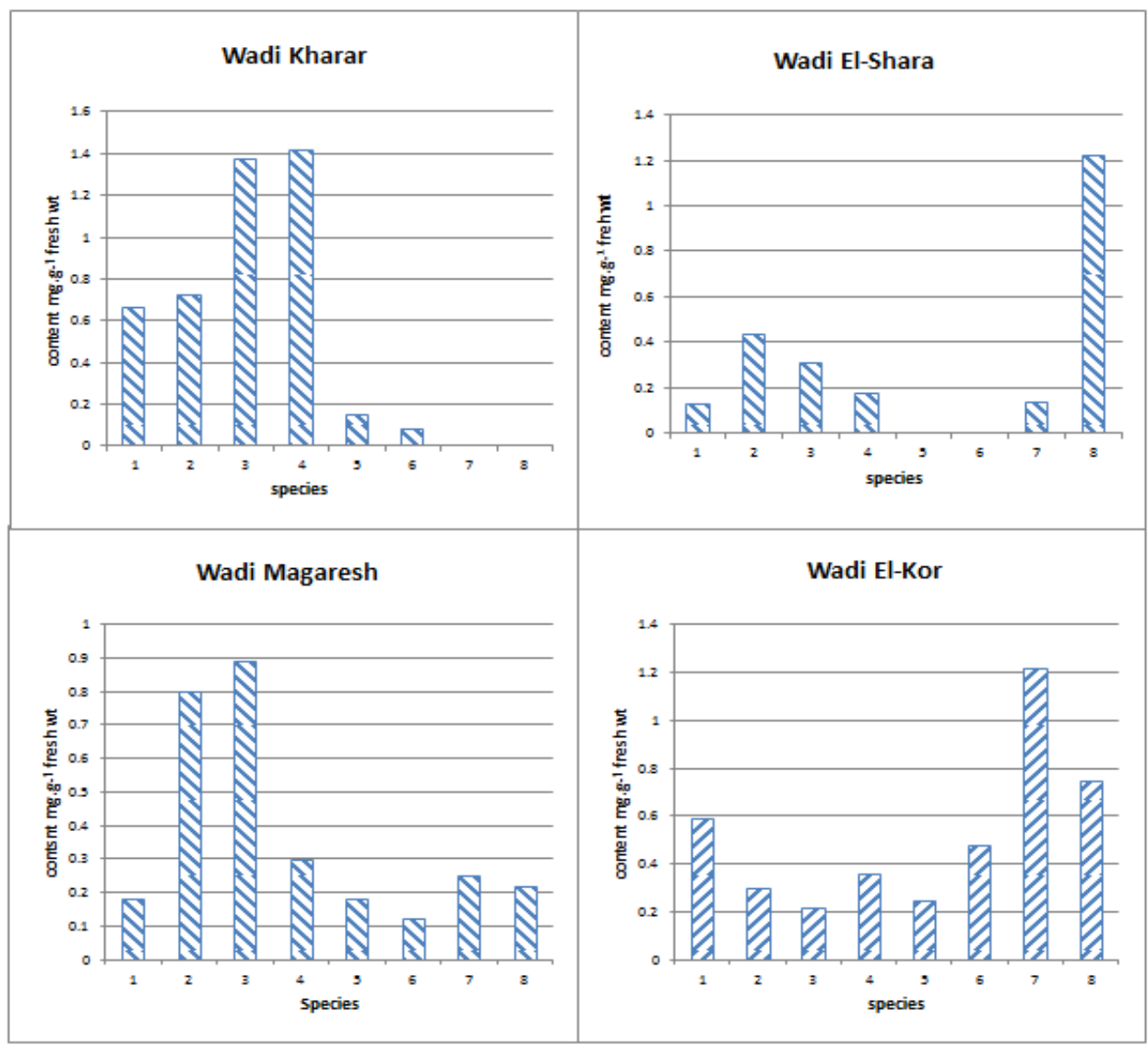

Figure (10): Average values of soluble sugars in different species inhabiting wadi Kharar, wadi El-Shara, wadi Magaresh and wadi El-Kor : (1) C. droserifolia; (2) A.pannosum; (3) T. desertorum; (4) C. colocynthis;(5) H. arbainense; (6) R.vesicarius; (7) D. innoxia; (8) C. russeliana.

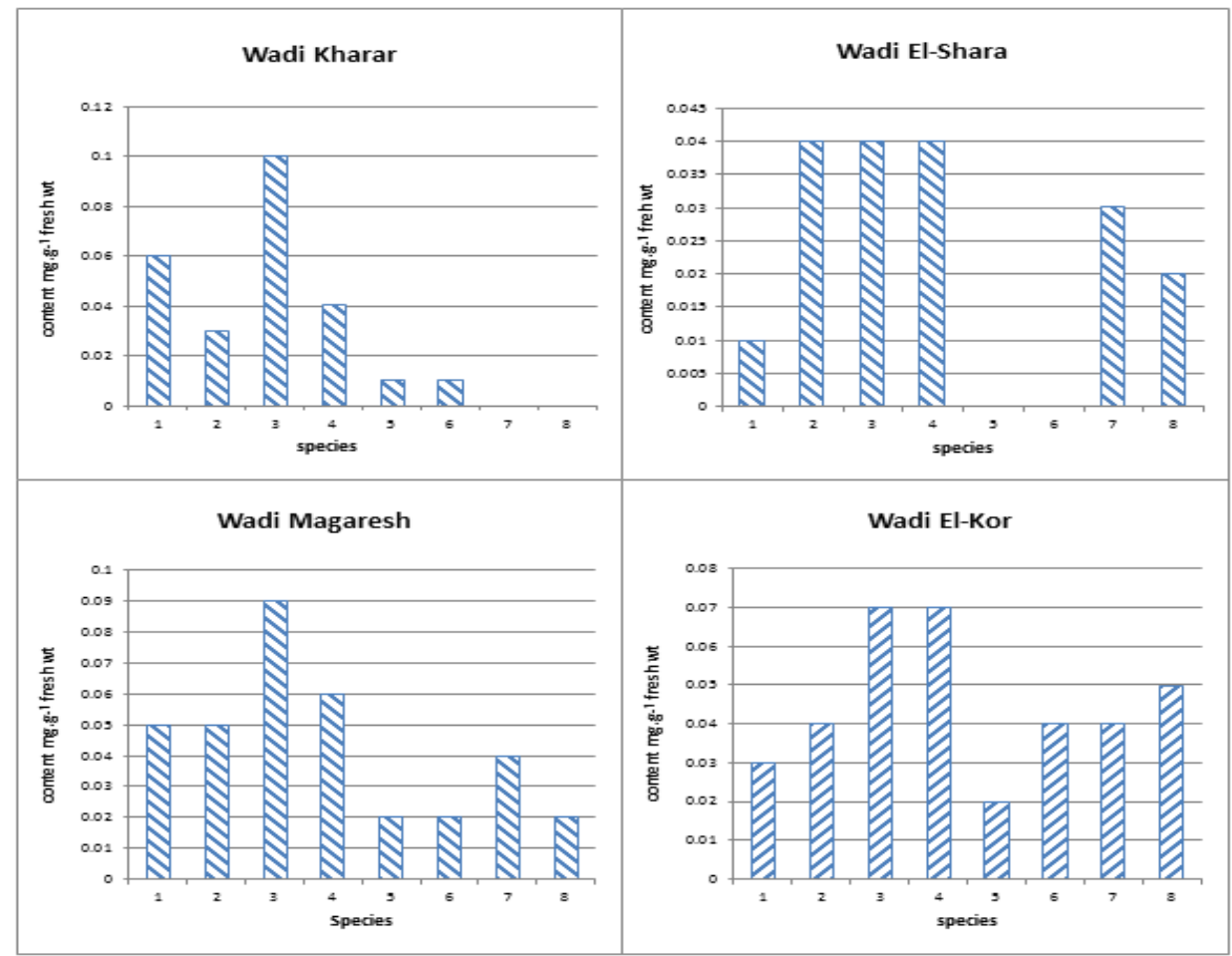

Figure (11): Average values of Soluble proteins in different species inhabiting wadi Kharar, wadi ElShara, wadi Magaresh ,wadi El-Kor. : (1) C. droserifolia; (2) A.pannosum; (3) T. desertorum; (4) $C$. colocynthis; (5) H. arbainense; (6) R.vesicarius; (7) D. innoxia; (8) C. russeliana. 
Table (5): ANOVA test showed the effect of wadis ,species and their interaction on soluble sugars , soluble proteins and $\mathrm{Mg}$ of investigated species of different floristic groups

\begin{tabular}{|c|c|c|c|c|c|c|}
\hline $\begin{array}{l}\text { Floristic } \\
\text { group }\end{array}$ & species & $\begin{array}{l}\text { Total chl } \\
\text { \& soluble } \\
\text { sugar }\end{array}$ & $\begin{array}{l}\text { Total CSI \& } \\
\text { soluble sugar }\end{array}$ & $\begin{array}{c}\text { Total chl } \\
\text { \& soluble } \\
\text { protein }\end{array}$ & $\begin{array}{c}\text { Total CSI \& } \\
\text { soluble } \\
\text { protein }\end{array}$ & D.F \\
\hline \multirow{4}{*}{ 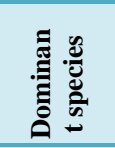 } & C.droserifolia & 0.636 & $-0.994 * *$ & -0.358 & -0.272 & \multirow{4}{*}{$\prod_{\pi}^{\pi}$} \\
\hline & A.pannosum & -0.420 & 0.046 & 0.722 & -0.308 & \\
\hline & T.desertorum & -0.458 & -0.793 & 0.788 & -0.517 & \\
\hline & C. colocynthis & -0.661 & 0.292 & 0.707 & -0.247 & \\
\hline \multirow{4}{*}{ 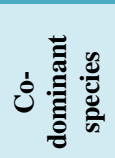 } & H. arbainense & $0.990 * *$ & -0.723 & 0.384 & $-0.958 *$ & \multirow{4}{*}{ 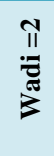 } \\
\hline & R.vesicarius & $-0.976^{*}$ & 0.903 & -0.853 & $0.993^{* *}$ & \\
\hline & D.innoxia & 0.635 & -0.848 & $0.955^{*}$ & 0.162 & \\
\hline & C. russeliana & 0.324 & -0.355 & -0.921 & 0.914 & \\
\hline
\end{tabular}

\section{Correlation between chlorophyll content and CSI with experimented metabolites:}

The most significant correlations between chlorophyll content and soluble sugars in the co-dominant species were positive (Table 8) with some exceptions. The same was true with soluble proteins. However, there were no significant correlations existed between total chlorophyll with both soluble sugars and soluble proteins of the dominant species. On the other hand, the total CSI was negatively correlated with soluble sugars of $C$. drosrifolia. The same correlation was found between CSI and S. proteins of $H$. arbainense, while mean, a positive correlation existed in case of $R$. vescarius (co-dominant species).

Table (6): Correlation coefficient (r.) values between total chlorophyll and its stability(CSI) with soluble sugars, soluble proteins in different studied species.

\begin{tabular}{|c|c|c|c|c|c|}
\hline \multirow{3}{*}{ contents } & \multirow{3}{*}{ Source of variance } & \multicolumn{2}{|c|}{ Dominant species } & \multicolumn{2}{|c|}{ Co dominant species. } \\
\hline & & $\mathbf{F}$ & n2 & $\mathbf{F}$ & $n^{2}$ \\
\hline & & & & & \\
\hline \multirow{3}{*}{$\begin{array}{c}\text { Soluble } \\
\text { sugars }\end{array}$} & Wadi & $15.808^{* * *}$ & 0.353 & $5.630 *$ & 0.238 \\
\hline & species & 1.077 & 0.047 & $3.841^{*}$ & 0.182 \\
\hline & Wadi x species & $16.049 * *$ & 0.601 & $11.843^{* *}$ & 0.581 \\
\hline \multirow{3}{*}{$\begin{array}{l}\text { Soluble } \\
\text { proteins }\end{array}$} & Wadi & 0.310 & 0.044 & $4.289^{*}$ & 0.222 \\
\hline & species & 2.222 & 0.261 & 3.230 & 0.222 \\
\hline & Wadi $x$ species & 1.183 & 0.696 & $3.676^{*}$ & 0.556 \\
\hline
\end{tabular}

\section{Discussion}

Drought and extreme temperatures cause a water deficit in plants. Data presented clarified that, succulent and annuls species had a high values of water content. Low water content was detected in the xerophyte A. pannosum, particularly at W. El-Kor which was inhabited by species had a low mean values of water content. The $\mathrm{F}$ and $\mathrm{n}^{2}$ values indicated that, the water content in plants was mainly affected by the interaction ( wadi $\mathrm{x}$ species ). While the species factor played the secondary role.

The intrinsic photo synthetic water use efficiency tended to rise than decline as the water stress increases in natural habitats (Pennings et al., 2005). Therefore, the arid climate affects the synthesis of essential pigments of plants. Richardson et al. (2002) reported that, the chlorophyll $a$ and chlorophyll $b$ are the most important of these pigments, and are thus virtually for the oxygenic conversion of light energy to the stored chemical energy that power of the biosphere. Obviously in this work, the high mean values of both chlorophyll $a$ and chlorophyll $b$ exerted by species inhabited W. El-Kor, and a low mean values was produced by species at W. El Shara. Generally, the results hitherto showed an increase in chlorophyll $a$ content more than that of chlorophyll $b$ and the succulent $C$. russeliana exhibited low levels of pigmentation. Among species, $T$. desertorum had high contents of chlorophyll $a$ and chlorophyll $b$, as well as the total chlorophyll (chlorophyll $a$ and chlorophyll $b$ ). This mechanism of resistance to PSII against photo damage may contribute to plant protection against chlorophyll destruction (Sharma and Hall, 1992; Farghali, 1998; Farghali and Rayan, 2005). In agree with Farghali (1998), Liu and Guan (2012) believe that the abundance of sunlight and lack of water in arid environments selects for plants with reduced $\mathrm{Chl}$ a content in the photosynthetic reaction center and for 
reduced size of the antenna chlorophyll protein complex so as to reduce the absorbed light energy and the generation of free radicals.

On other hand, the chlorophyll $a / b$ ratio slightly changed among studied species, where a low value was detected in T.desertorum. This means that, increased chlorophyll fractions corresponding to decreasing of chlorophyll $a / b$ ratio. Furthermore, the mean values of this ratios could be emphasized this view where the high chlorophyll $a / b$ ratio was yielded by species at W. El-Shara and a low value was found in species at W. El-Kor. Farghali (1998) concluded that, the adaptation of plants in their natural habitats to enduring drought and high temperatures are due to decreased chlorophyll $a / b$ ratios balanced by increased chlorophyll stability to heat (CSI). This was true in case of CSI of chlorophyll $a$ in most species inhabited W. Al Noman tributaries. The succulent $C$. russeliana had a low CSI of chlorophyll $a$. Whereas, $T$. desertorum yielded a high CSI of chlorophyll $a$, the stability of chlorophyll $b$ to heat was decreased. This was true in case of $R$. vescarius (annual), which means that the species strategies against chlorophyll destruction depend on the alternation of CSI between chlorophyll $a$ and chlorophyll $b$. Thus PSII appears to be most heat sensitive within the photosynthetic apparatus of plants in arid and semi-arid regions (Aro et al., 1993). Therefore, the total CSI of both chlorophyll $a$ and chlorophyll $b$ was slightly changed among investigated species. In general, the increase in CSI and/or chlorophyll accumulation is indicative of high efficiency of photosynthetic apparatus under extreme conditions (Farghali, 1998; Farghali and Rayan, 2005). In some instances of the studied species, the chlorophyll content was positively correlated with CSI. Conversely, the negative correlation between chlorophyll content and its stability to heat in such species as $C$. russeliana means that, CSI depends on the resistance of chloroplast membrane to heat, and consequently it is helpful in indicating adaptations in such species (Ristic and Cass, 1992). The chlorophyll content greatly affected by the single factors (wadi and species) factors and their interaction which had a highly significant effects with some exceptions. In general, this interaction had a dominant role on the chlorophyll $a$, chlorophyll $b$, chlorophyll $a / b$ and total chlorophyll content in different floristic groups. The role of secondary was variable, where the species factor had a role on chlorophyll parameters mentioned above in different groups, except in case of dominant species, the chlorophyll $a$ and total chlorophyll contents were affected by the wadi factor. Whereas the interaction (wadi x species) had a highly significant, and the predominant role on the CSI of dominant and co-dominant species.

Chlorophyll content gives an indicator measure of nutrient status (Moran et al., 2000; Richardson et al., 2002). Hence, Mg participates in chlorophyll building and enhancing pigment content. Accordingly, a significant positive correlation between chlorophyll content and $\mathrm{Mg}^{+2}$ in tested species (e.g. H. arbainense) was due to consumption of $\mathrm{Mg}$ ions during chlorophyll construction. Conversely, negative correlation, (e.g. $C$. russeliana) means a destruction of chlorophyll content may be due to excessive excitation energy when high temperature was combined with high light (Chen et al., 2004; Farghali and Rayan, 2005). Sometimes, the increased thermo stability of chlorophyll in wild species under drastic conditions was accompanied by increased $\mathrm{Mg}^{+2}$ ions (e.g. annual $R$. vescarius and succulent $C$. russeliana) and vice versa.

The adaptation of plants to heat stress induced accumulation of metabolites that serve as compatible solutes in chloroplasts which were related to enhance thermostability (Hasegawa and Bressan, 2000). This was true in case of succulent $C$. russeliana which had highest values of soluble sugars with increased CSI. Regardless of species, a high amount of soluble sugars was found in species inhabited W. Kharar, whereas the lowest mean values existed in species at W. El-Shara. Hence, the( wadi x species) interaction had a major role on the soluble sugars of different species. The wadi factor played the secondary role on soluble sugars of dominant and co-dominant species. There were positive correlations between soluble sugars and chlorophyll content in most studied species contributed to high efficiency of chlorophyll molecules (Rayan, 2004). The soluble sugars in such species as $R$. vescarius were negatively correlated with chlorophyll contents may be due to translocation of sugars to fruits, or to different plant parts, or carbon partitioning between sucrose and starch (Farghali and El-Sharkawi, 1990; Keutgen and Chen, 2001).

Apparently, the metabolic constituents in the investigated species exhibited the following pattern: soluble sugars $>$ soluble proteins. The interaction (wadi x species) had a significant effects on soluble proteins in co-dominant species, while a non-significant effect in case of soluble proteins in dominant species. Therefore this interaction played the main role on the soluble proteins. The subsidiary role on this nitrogen fraction in codominant species was exerted by the wadi factor. A positive correlation was shown between chlorophyll content and soluble proteins in D. innoxia (annual). This may explained that these species may tolerate drought in an account for reductions in chlorophyll content which in turn may cause changes in soluble proteins (Rayan and Farghali, 2007). While, CSI and proteins in $R$. vescarius (annual) was positively correlated, there were a negative correlations in case of $H$. arbainense, This means that, the adaptation of these plants to heat stress induced accumulation of water binding molecules and compatible solutes in chloroplasts which related to enhance thermostability (Hasegawa and Bressan, 2000). The pigmentation of many species was well established and balanced by the thermo stability of chlorophyll against high irradiance, heat and water stresses. Accordingly, the application of any cropping projects at desert wadis must be taken in consideration the 
interactive effects of biotic and abiotic variables on the productivity and conserve diversity of species grown in arid and semi-arid regions.

\section{References}

[1]. Akinci I.E., Akinci S., Yilmaz K. 2010. Response of tomato (Solanum lycopersicum L.) to lead toxicity: growth, element uptake, chlorophyll and water content. Afr. J. Agric. Res.;5:416-423.

[2]. Aro, E. M., Virgin, I. and Andersson, B. 1993. Photoinhibition of photo system II.. Inactivation, protein damage and turnover. Biochimica et Biophysica Acta, 1143(2): 113-134.

[3]. Boulos, L. 1999, 2000, 2002, 2005. Flora of Egypt Checklist. Cairo :Al Hadara Publishing.

[4]. Chen, H., Li, W., An, S. and Gao, T. 2004. Characterization of PSII photochemistry and thermostability in salt treated Rumex leaves. Journal of Plant Physiology, 161(3): 257-2264.

[5]. Collenette, S. 1985. An Illustrated Guide to the Flowers of Saudi Arabia. London: Scorpion.

[6]. Curran, P. J., Dungan, J. L. and Gholz, H. L. 1990. Exploring the relationship between reflectance red edge and chlorophyll content in slash pine. Tree Physiology, 7(1-2-3-4): 33-48.

[7]. Dubois, M., Gilles, K. A., Hamilton, J. K., Rabers, P. A. and Smith, F. 1956. Colorimetric method for the determination of sugars and related substance. Analytical Chemistry, 28(3): 350-356.

[8]. El-Sharkawi, H. M. and Springuel, I. 1977. Germination of some crop plant seeds under reduced water potential. Seed Science and Technology, 5(4):677-688.

[9]. Farghali, K. A. 1998. Chlorophyll content and its stability in native species inhabiting the Egyptian Desert. Journal of Arid Environments, 40(2): 163-175.

[10]. Farghali, K. A. 1998. Diurnal variations of chlorophyll and dry matter content of Senna occidentalis in response to zinc and soil moisture. Biologia Plantarum, 40: 419-424.

[11]. Farghali, K. A. and El-Sharkawi, H. M. (1990): Interactive effects of water stress, NPK-nutrients and irradiance on chlorophyll content and metabolites in cotton seedlings . Journal of the Faculty of Science, United Arab Emirates, 2:31-42 .

[12]. Farghali, K. A. and Rayan, A. M. 2005. Chlorophyll stabilization in some succulent and non-succulent species inhabiting Kharga and Dakhla oasis in Egypt. Assiut University Journal of Botany, 34 (2): 391-409.

[13]. Filella, I., Serrano, L., Serra, J. and Peñuelas, J. 1995. Evaluating wheat nitrogen status with canopy reflectance indices and discriminant analysis. Crop Science, 35(5): 1400-1405.

[14]. Hasegawa, P. M. and Bressan, R. A. 2000. Plant cellular and molecular responses to high salinity. Annual Review of Plant Physiology and Plant Molecular Biology, 51: 463-499.

[15]. Keutgen, N. and Chen, K. 2001. Responses of citrus leaf photosynthesis, chlorophyll fluorescence, macronutrient and carbohydrate contents to elevated CO2. Journal of Plant Physiology, 158(10): 1307-1316.

[16]. Lichtenthaler, H.K. 1987. Chlorophyll and Carotenoids: Pigments photosynthetic biomembranes. Meth. Enzyme, 148:331-382.

[17]. Liu ,N.and Guan, L. 2012. Linkages between woody plant proliferation dynamics and plant physiological traits in southwestern North America. Journal of Plant Ecology 5:4, 407-416

[18]. Lowry, O. H., Rosebrough, N. J., Farr, A. L. and Randall, R. J. 1951. Protein measurement with the folin phenol reagent. Journal of Biological Chemistry, 193(1): 265-275.

[19]. Migahid, A. M. 1978. Migahid and Hammouda's Flora of Saudi Arabia. Saudi Arabia : Riyadh University Publication.

[20]. Moran, J. A., Mitchell, A. K., Goodmanson, G. and Stockburger, K. A. 2000. Differentiation among effects of nitrogen fertilization treatments on conifer seedlings by foliar reflectance: a comparison of methods. Tree Physiology, 20(16): 1113-1120.

[21]. Murty, K. S. and Majumder, S. K. 1962. Modifications of technique for determination of chlorophyll stability index in relation to studies of drought resistance in rice. Current Science, 31: 470-471.

[22]. Ostle, B. 1963. Statistics in Research. Iowa: Iowa State University Press, Ames.

[23]. Pennings, S. C. ,Grant, M. B. and Bertness, M. D. 2005. Plant zonation in low latitude salt marshes : disentangling the role of flooding, salinity and competition .Journal of Ecology, 93(1): 159-167.

[24]. Ploxinski, N. A. 1969: rucovodstro po biometrii dlya zootexnikov. Izdatel'stvo "Kolos" Moskow.

[25]. Rayan, A. 2004 .Seasonal variation in chlorophyll and sugar contents in some desert species. Bulletin of the Faculty of Science, Assiut University, 33(2): 61-70.

[26]. Rayan, A. M. and Farghali, K. A. 2007. Seasonal changes in nitrogen metabolites and $\mathrm{Na}^{+} / \mathrm{K}^{+}$ratio in some desert species. Acta Botanica Hungarica, 49(3): 385-400.

[27]. Richardson, A. D., Duigan, S. P. and Berlyn, G. P. 2002. An evaluation of noninvasive methods to estimate foliar chlorophyll content. New Physiologist, 153(1): 185-194.

[28]. Ristic, Z. and Cass, D. D. 1992. Chloroplast structure after water and high temperature stress in two lines of maize that differ in endogenous levels of abscisic acid. International Journal of Plant Sciences, 153(2): 186-196.

[29]. Stewart, E. A. 1974. Chemical analysis of an ecological material. Blackwell scientific Publication Oxford. London, Edinburg Melbourne.

[30]. Sharma, P. K. and Hall, D. O. 1992. Changes in carotenoid composition and photosynthesis in sorghum under high light and salt stresses. Journal of Plant Physiology, 140(6): 661-666.

[31]. Täckholm, V. 1974. Students' Flora of Egypt. 2nd Edition. Cairo: Cairo University Press. 888 pp. 